\title{
Ricardian Equivalence: Evidence From South American Countries
}

Khan A. Mohabbat, (E-mail: kmohabbat@niu.edu), Northern Illinois University Mohammad Ashraf, (E-mail: mohammad.ashraf@uncp.edu), University of North Carolina at Pembroke

\begin{abstract}
This study deals with the intergenerational effect of national debt. We try to find out whether the government deficit incurred today has any adverse effect on the generations to come. More specifically, this study tests the notion that any deficit acquired by the government today is offset by the private sector by reducing their consumption and increasing their savings to pay for the debt some times in the future. Since the time horizon for the government is longer than that of the private agents, the private agents altruistically bequeath what they have saved along with interest earned to their offsprings. This study empirically verifies the debt neutrality hypothesis for several South American countries for which workable data were available. The results do not support the debt neutrality hypothesis and show that economic agents consider government bonds net wealth affecting their consumption in a positive way.
\end{abstract}

\subsection{Introduction}

Although national debt has been a matter of concern over the decades, the enormous size of the recent national debt has made it the focal point of urgent discussion over the last two decades. Deliberations on national debt have taken place in academic circles, the press, and the financial and political arenas. The effect of national debt on the economy is multidimensional. We shall limit our discussion to the effect of national debt on the future generations. Before we address the significance of intergenerational national debt, let us briefly look at some background material. National debt arises when government carries over time, budgets that are strewn with deficits. The sum total of the annual deficits, minus surplus if any, makes the national debt. Since national debt and annual deficits are intricately related, concentrating on the economic effects of deficits is operationally more feasible than on the global nature of debt.

Deficits are of two types. One, cyclical deficit that comes into existence when the economy is operating at a level less than full employment and the government needs to mitigate low economic activity by stimulating the economy via the automatic stabilizers or discretionary fiscal policy. The second type of deficit arises even when the economy is at the potential output level. This type of deficit is called structural deficit. Cyclical deficit is considered by most a necessary evil; whereas, structural deficit is not. Smaller annual deficit may be tolerable. However, prolonged large deficits are considered, by many, as harmful to the efficient working of the economy.

It is argued that large deficits do affect interest rate, produce large trade deficit, redistribute income, reduces national saving, investment and retards the growth of capital stock. The slow down in the growth rate of capital accumulation is harmful to future generations.

It is also argued that large budget deficits result in large trade deficits. This argument works through two channels. The first avenue is the expansionary fiscal policy, which raises domestic inflation and encourages imports and discourages exports. The second route is through the interest rate. Here large deficits raise domestic interest rate, which

Readers with comments or questions are encouraged to contact the authors via email. 
induces foreign investors to buy domestic debt resulting in appreciation of the domestic currency. High value of domestic currency helps imports but hurts exports.

In addition large national deficits, in order to be paid in the future, requires that tax rates would have to be raised in the future. Increase in taxes may cause distortions making the functioning of the economy less efficient. Such a cost, loss in productivity, would be imposed on the future generations. Another consequence of large national debt is the redistribution of income. Taxes are imposed on all to pay for the repayment of debt and its interest, whereas bond holdings are not uniformly distributed.

One of the most talked about harms of the national deficit is that it reduces national saving. Lower national saving is harmful to future capital formation, which results in lower standard of living of the future generation. Briefly stated, deficit spending by the government increases current disposable income and consumption leaving lower levels of resources for investment for the future. Lower investment over time results in lower productive capital to be passed on to the coming generations depriving them of the otherwise higher standard of living. Such a phenomenon is called the real burden of national debt. This notion has strong support in the financial press, political circles and the academia. But there are a number of skeptics, both on theoretical as well as empirical grounds. For instance the tax reduction of the 1980's in the United States created a surge in consumption. However, it is difficult to ascertain whether this wave of spending was due to the increase in after tax income or consumer optimism of the Reagan era. By the same token, it is uncertain that the high real interest rates that prevailed in the 1980's were due to the government deficits or a host of other exogenous influences on consumption, investment and other components of aggregate demand.

On theoretical grounds, Robert Barro (1974 and 1981) challenges the notion of national debt burden and argues that the effect of national debt on the economic activity is neutral. Hence, the debt neutrality proposition. Barro does this by invoking the Ricardian Equivalence proposition. The origin of this theorem goes back to David Ricardo who contended that public expenditure financed by deficit in issuing government bonds would have no significant effect on the private agent spending pattern so long as the agent and the government have the same time horizon. The private sector would regard the deficit spending as equivalent to future taxation, required to pay for the future payments of interest and principal. In this scenario government deficit is not viewed as net wealth by economic agents. Thus, it cannot affect the real variables.

Using the overlapping generation model, under a number of restrictive assumptions, Barro showed that for a given path of government spending, the choice between the time pattern of taxes and government bonds has no effect on the private sector wealth or consumption. This implies that government bonds will not be perceived as net wealth by the private sector and will be considered as future obligation in the form of future taxes. Consequently the dissaving in the public sector will be matched by private saving leaving the overall national saving unchanged. This conclusion holds even though the time horizon of the government is different from the private agents so long as the families are linked across generations through gifts and bequests.

There are a number of studies that have supported the Ricardian Equivalence. Evans (1985, 1987, 1983), Hoelscher (1983), Plosser (1982) and Darrat (1990) have shown little or no relation between large deficits and the interest rates for the United States. The conclusion is that consumers are more prone to Ricardian Equivalence in their response to national deficit.

The debt neutrality proposition has been criticized on several grounds. Even though Barro uses intergenerational links to connect the present generation to the future, to bequeath an amount equal to the deficit to be paid back by the offsprings, requires sufficient amount of caring to incorporate children's welfare into the parents' utility functions (Weil 1987). Kotlikoff and Summers (1981) have found that such utility functions that incorporate the welfare of the children seldom exist even when parents love their children.

Bernheim, Shleifer and Summers (1985) give bequest "strategic" motives in which funds are being left for offsprings not for the purpose of paying their share of the national debt, but to make them observe a code of behavior that is respectful to the parents. 
An alternative to money bequest is human capital investment transfer, in which parents pay for children's education so that they can provide for themselves a better future. In this case deficits that are incurred via tax reduction will increase expenditure and will not remain neutral with respect to the economic activity. Of course, then, there is the case of the childless parents who need not make such provision (Tobin and Buiter 1979).

Feldstein's (1976) argument against the debt neutrality proposition takes a different route. He argues that it is the ratio of national debt to GDP that is important. So long as the debt growth rate is not greater than that of the GDP, the parent generation has no reason to augment their bequest to the offsprings. In addition, Feldstein also argues that uncertainty regarding future income levels can also increase current consumption should there be a tax reduction. Since, the debt neutrality proposition is based on a fixed course of government spending, it certainly complicates the outcome should spending be related to government revenue. Furthermore, should tax cut be income based rather than lump sum, it will affect economic agent's behavior towards work and leisure resulting in augmentation of consumption spending. If bequest were subject to progressive income taxes, this too could be a hindrance to debt neutrality proposition.

Hirschorn (1984) using Barro's apparatus in the context of rational expectation model comes to the nonneutrality conclusion of the deficit. He argues that even economic agents under rational expectations, having all the available information on the structure of the economy including the underlying stochastic process of fiscal policy, can only anticipate the systematic portion of the bond issuance not the white noise portion. The unanticipated portion of the government bonds will constitute net wealth producing a positive effect on consumption. The uncertainty of future tax incidence also creates impediments to debt neutrality even when one acknowledges the presence of operative bequests. In the presence of the uncertainty of the tax incidence, the existence of future tax liability does not necessarily offset the effects of current tax cut on consumption. In addition, debt neutrality also tacitly assumes that there are no liquidity constraints on economic agents. However, a liquidity-constrained individual, even when the agent bases consumption on life-time resources and observes bequest operatives, will spend part of his/her increased income on consumption (Leiderman and Beljer 1986). This is so because due to the financial market imperfections the individual may be unable to borrow against future income. In the presence of binding borrowing constraints, deficit resulting from a tax cut will reduce national saving and raise the real interest rate.

The plan of the study is as follows: Section II presents the models to test whether debt neutrality theorem holds for the four South American countries; namely, Costa Rica, El Salvador, Guatemala and Uruguay. The choice of the countries was solely based on data availability. Section II also presents the empirical results. Section III makes the concluding remarks.

\subsection{Model Specifications and Empirical Results}

In this section we wish to ascertain whether debt neutrality hypothesis holds in the case of the four Latin American countries; specifically, Costa Rica, Guatemala, El Salvador and Uruguay. If the debt neutrality hypothesis holds, the increase in government deficit should trigger consumer behavior in such a way that economic agents cut their current consumption by an equivalent amount and save the funds to repay the debt in the future. If the Ricardian Equivalence does not hold the increase in debt will not have negative influence on consumption expenditures leaving either consumption unchanged or augmented should the economic agents consider government bonds as an addition to their wealth.

To test the debt neutrality hypothesis we use a wealth based consumption function of the following form:

$C_{t}=a_{0}+a_{1} Y_{t}+a_{2} C_{t-1}+a_{3} T D_{t}+e_{t}$

$e_{t}=b e_{t-1}+v_{t}$

Where $\mathrm{C}$ represents consumption, $\mathrm{Y}$ the level of income and TD the total government deficit. Subscripts $\mathrm{t}$ and $\mathrm{t}-$ 1 refer to the current period and one period lag. The term $e_{t}$ may be AR1 and $v$ has the usual properties of white noise error term. All variables are on real per capita basis to control for population growth and price changes. 
The consumption function used here conforms to the life-cycle permanent income hypothesis of Ando and Modigliani (1963) and Friedman (1957). It is broad enough to incorporate the insight associated with the Hall (1978) version of the permanent income hypothesis under rational expectations. The per capita consumption is modeled to depend on per capita income, one-period lagged consumption, and per capita government deficit. The inclusion of $\mathrm{C}_{\mathrm{t}-1}$ is a proxy for wealth and it also takes into account the habit persistence notion, as it is applicable to consumer behavior.

Furthermore, it conforms to the rational expectation hypothesis, which requires that all the relevant information be used in predicting consumption. Hall argues that $\mathrm{C}_{\mathrm{t}-1}$ contains, up to the period $\mathrm{t}-1$, all the relevant information, including wealth that affects the current consumption. Any new information after $\mathrm{t}-1$, which is not contained in $\mathrm{C}_{\mathrm{t}-1}$ would have to be accounted for to estimate the current consumption. $\mathrm{Y}_{\mathrm{t}}$ is such post $\mathrm{t}-1$ period information, which needs to be taken into consideration. This is especially important when money and capital markets do not behave competitively causing liquidity constraints and preventing consumers from borrowing on the strength of their future incomes. Liquidity constrained individuals are likely to have consumption based on constrained current income rather than permanent income. To make sure that we have taken into consideration the sensitivity of consumption to current income, in a world of imperfect credit markets, we include current income into the consumption specification.

The empirical results for specification (1) testing the debt neutrality proposition are presented in Table 1 below. For the Ricardian equivalence to hold the sign of the deficit parameter must be negative and equal to one, and the sign of the income parameter be zero.

The evidence presented in Table 1 show that debt neutrality hypothesis does not hold in the four South American countries under consideration. The negative sign of the total deficit coefficients obeys the Ricardian Equivalence dictum for Costa Rica, Guatemala and Uruguay. However, the values of the coefficients are statistically insignificant at the 5\% (or any other reasonable) significance level. What this implies is that private agents do not lower their current consumption spending to save funds for the repayment of the current deficit at some future date.

Table 1

$\mathrm{C}_{\mathrm{t}}=\mathrm{a}_{0}+\mathrm{a}_{1} \mathrm{Y}_{\mathrm{t}}+\mathrm{a}_{2} \mathrm{C}_{\mathrm{t}-1}+\mathrm{a}_{3} \mathrm{TD}_{\mathrm{t}}+\mathrm{e}_{\mathrm{t}}$

$e_{t}=b e_{t-1}+v_{t}$

\begin{tabular}{|l|c|c|c|c|}
\hline Coefficients & $\begin{array}{l}\text { Costa Rica } \\
(1970-99)\end{array}$ & $\begin{array}{l}\text { El Salvador } \\
(1970-99)\end{array}$ & $\begin{array}{l}\text { Guatemala } \\
(1970-96)\end{array}$ & $\begin{array}{l}\text { Uruguay } \\
(1970-96)\end{array}$ \\
\hline & & & & \\
\hline $\mathrm{a}_{0}$ & -16.4 & 202.32 & -5.78 & -0.96 \\
& $(-0.59)$ & $(0.40)$ & $(-0.60)$ & $(-0.38)$ \\
\hline $\mathrm{a}_{1}$ & $0.0075^{\mathrm{b}}$ & 0.25 & 0.001 & 0.03 \\
& $(2.50)$ & $(0.39)$ & $(0.47)$ & $(2.07)$ \\
\hline $\mathrm{a}_{2}$ & 0.35 & -0.99 & $0.59^{\mathrm{b}}$ & -0.11 \\
& $(1.25)$ & $(-0.48)$ & $(2.27)$ & $(-0.27)$ \\
\hline $\mathrm{a}_{3}$ & -0.19 & 4.88 & -0.13 & -3.00 \\
& $(-0.52)$ & $(0.03)$ & $(-0.25)$ & $(-1.43)$ \\
\hline $\mathrm{b}$ & 0.22 & 0.06 & 0.06 & -0.32 \\
& $(0.61)$ & $(0.03)$ & $(0.18)$ & $(-0.74)$ \\
\hline Total R & 0.26 & 0.5264 & 0.3605 & 0.24 \\
\hline
\end{tabular}

Significance Level: ${ }^{\mathrm{a}}=1 \%{ }^{\mathrm{b}}=5 \%{ }^{\mathrm{c}}=10 \%$ (t-stats in parentheses)
As far as the other variables are concerned, permanent-life cycle notion of consumption holds only in the case of Guatemala. This is evidenced by the positive and significant parameter estimate of the one period lagged consumption. Lagged consumption is used to convey proxy information on wealth. A rather surprising result is the insignificance of the income coefficient estimates in the consumption specification for El Salvador, Guatemala, and Uruguay. In the case of Costa Rica, although the coefficient is positive and significant, the magnitude is rather small. Considering the imperfection in the credit markets it would have been more reasonable to expect that the liquidity constrained

individuals augment their consumption spending by using current income. But such is not the case. Upon reflection and examination of the data it becomes clear that per capita real income has moved very slightly during the sample period. When income is relatively stable, current income does not diverge from permanent income by much. In such an event the explanatory power of current income in the consumption equation is absorbed by permanent income. 
Specification (2) is presented as an alternative way to test the Ricardian Equivalence.

$$
\begin{aligned}
& C_{t}=a_{0}+a_{1} Y_{t}+a_{2} C_{t-1}+a_{3} B_{t}+a_{4} F_{t}+a_{5} M_{t}+e_{t} \\
& e_{t}=b e_{t-1}+v_{t}
\end{aligned}
$$

The deficit variable is divided into three components to test the debt neutrality hypothesis. BD is the real per capita domestically held portion of the total deficit, FD is the real per capita foreign held segment of the newly created debt and MD is the real per capita monetized component of the deficit that is held by the central banks. The main reason for partitioning the national deficit is that the economic impact of the three components is not the same on consumers. To begin with, the monetized portion of the newly created debt has the same effect on the economy as the creation of new money. In a real sense it is a tax in the form of inflation. This segment of the deficit is not really a true debt. The nonmonetized portion represents the true debt for which the future generations are responsible. However, not all nonmonetized category of deficit adds to the wealth of the private sector; only the domestically held portion BD may do that. Hence, the further division between BD and FD to see whether economic agents behave differently with respect to bonds held domestically or by foreign nationals. Under debt neutrality proposition the coefficients of the two variables should be equal with negative signs and must sum to unity.

The empirical results are presented in Table 2. The trichotomized version of the total deficit brings in an added insight into the debt neutrality hypothesis. The coefficients of $\mathrm{BD}$, the domestically held bond portion of the deficit, have become statistically insignificant for all four countries with some sign switching. Since none are significantly different from zero, little importance can be attached to them.

Table 2

$\mathrm{C}_{\mathrm{t}}=\mathrm{a}_{0}+\mathrm{a}_{1} \mathrm{Y}_{\mathrm{t}}+\mathrm{a}_{2} \mathrm{C}_{\mathrm{t}-1}+\mathrm{a}_{3} \mathrm{BD}_{\mathrm{t}}+\mathrm{a}_{4} \mathrm{FD}_{\mathrm{t}}+\mathrm{a}_{5} \mathrm{MD}_{\mathrm{t}}+\mathrm{ET}$

$\mathrm{e}_{\mathrm{t}}=\mathrm{be}_{\mathrm{t}-1}+\mathrm{v}_{\mathrm{t}}$

\begin{tabular}{|l|c|c|c|c|}
\hline Coefficients & $\begin{array}{c}\text { Costa Rica } \\
(1970-99)\end{array}$ & $\begin{array}{c}\text { El } \\
\text { Salvador } \\
(1970-99)\end{array}$ & $\begin{array}{c}\text { Guatemala } \\
(1970-96)\end{array}$ & $\begin{array}{c}\text { Uruguay } \\
(1970- \\
96)\end{array}$ \\
\hline & & & & \\
\hline $\mathrm{a}_{0}$ & -3.01 & 266.45 & -13.37 & -1.93 \\
$(-0.09)$ & $(0.66)$ & $(-1.33)$ & $(-0.66)$ \\
\hline $\mathrm{a}_{1}$ & $0.007^{\mathrm{b}}$ & 0.24 & 0.003 & 0.02 \\
& $(2.27)$ & $(0.31)$ & $(1.13)$ & $(1.62)$ \\
\hline $\mathrm{a}_{2}$ & 0.35 & -0.98 & $0.55^{\mathrm{b}}$ & -0.31 \\
& $(1.17)$ & $(-0.69)$ & $(2.20)$ & $(-1.00)$ \\
\hline $\mathrm{a}_{3}$ & -0.03 & -6.68 & 0.31 & 1.2 \\
& $(-0.07)$ & $(-0.11)$ & $(0.52)$ & $(0.55)$ \\
\hline $\mathrm{a}_{4}$ & -0.31 & -88.21 & -0.36 & 10.6 \\
& $(-0.45)$ & $(-0.39)$ & $(-0.15)$ & $(1.76)$ \\
\hline $\mathrm{a}_{5}$ & 1.07 & -71.59 & -1.97 & 2.27 \\
& $(0.53)$ & $(-0.24)$ & $(-1.49)$ & $(0.98)$ \\
\hline $\mathrm{b}$ & 0.19 & 0.08 & 0.22 & -0.44 \\
& $(0.49)$ & $(0.06)$ & $(0.73)$ & $(-1.41)$ \\
\hline Total $\mathrm{R}^{2}$ & 0.27 & 0.53 & 0.45 & 0.2913 \\
\hline
\end{tabular}

Significance Level: ${ }^{\mathrm{a}}=1 \% ;^{\mathrm{b}}=5 \% ;{ }^{\mathrm{c}}=10 \%$ (t-stats in parentheses)
The monetized component of the deficit, MD, has produced unconventional results. One would expect that monetary expansion resulting from deficit financing to have positive effect on consumption; since, it provides added liquidity to the system. Such is not the case here. The consumption spending in El Salvador and Guatemala has reacted negatively and in Costa Rica and Uruguay positively to the rise of monetized debt. Upon close analysis it is evident that as a consequence of money creation inflation has been rampant resulting in inefficiency in the production process. When inflation is widespread much effort that would have been used in productive endeavors is being used in portfolio reallocation to guard against inflation. Such attempts, although quite rational for agents are not productive in the aggregate sense. That is to say, the negative coefficients of MD portray the strong indirect effect of money growth on consumption spending through inflation dislocation. The liquidity effect of money on consumption seems to be overwhelmed by its indirect impact through inflation. However, since the coefficient estimates are insignificant for all four countries, little weight can be attached.

The foreign held component of the total deficit, FD, again has uniformly statistically insignificant parameter estimates for all four countries. This result should not be surprising. The consumption expenditure of private agents has 
no reason to respond to deficit bonds held by foreigners. Certainly, foreign held portion cannot be considered an addition to wealth.

As far as the effects of the remaining variables on consumption, not much is changed from that of Table 1 . The overall results of Table 2 strongly reject the debt neutrality proposition that private agents reduce their consumption expenditure on a one to one basis in response to deficit. Such has not been the case in this study.

Next, we wish to attempt to verify the Ricardian Equivalence hypothesis by recasting the consumption specification as,

$$
\begin{aligned}
& C_{t}=a_{0}+a_{1} Y t+a_{2} C_{t-1}+a_{3} B D_{t}+a_{4} M D_{t}+e_{t} \\
& e_{t}=b e_{t-1}+v_{t}
\end{aligned}
$$

Where MFD is the sum of the monetized and foreign held portions of the newly created debt. The remaining variables are the same as before. The rational for the dichotomization of deficit into domestically held portion, $\mathrm{BD}$, and monetized plus foreign held segment, MFD, is that these components influence the economy differently. The influence of $\mathrm{BD}$ on consumption spending comes through its potential wealth effect in the consumer portfolio; whereas, MFD works through the liquidity effect that it provides the private agents. The estimated results are presented in Table 3 below.

Table 3

$\mathrm{C}_{\mathrm{t}}=\mathrm{a}_{0}+\mathrm{a}_{1} \mathrm{Y}_{\mathrm{t}}+\mathrm{a}_{2} \mathrm{C}_{\mathrm{t}-1}+\mathrm{a}_{3} \mathrm{BD}_{\mathrm{t}}+\mathrm{a}_{4} \mathrm{MFD}_{\mathrm{t}}+\mathrm{e}_{\mathrm{t}}$

\begin{tabular}{|c|c|c|c|c|}
\hline Coefficients & $\begin{array}{c}\text { Costa Rica } \\
(1970-99)\end{array}$ & $\begin{array}{c}\text { El } \\
\text { Salvador } \\
(1970-99)\end{array}$ & $\begin{array}{c}\text { Guatemala } \\
(1970-96)\end{array}$ & $\begin{array}{c}\text { Uruguay } \\
(1970- \\
96)\end{array}$ \\
\hline$a_{0}$ & $\begin{array}{c}-3.01 \\
(-0.09)\end{array}$ & $\begin{array}{c}266.46 \\
(0.66)\end{array}$ & $\begin{array}{l}-13.37 \\
(-1.33)\end{array}$ & $\begin{array}{l}-1.93 \\
(-0.66)\end{array}$ \\
\hline$a_{1}$ & $\begin{array}{l}0.007^{b} \\
(2.27)\end{array}$ & $\begin{array}{c}0.24 \\
(0.31)\end{array}$ & $\begin{array}{l}0.003 \\
(1.13)\end{array}$ & $\begin{array}{c}0.02 \\
(1.62)\end{array}$ \\
\hline$a_{2}$ & $\begin{array}{c}0.35 \\
(1.17)\end{array}$ & $\begin{array}{c}-0.98 \\
(-0.69)\end{array}$ & $\begin{array}{l}0.55^{b} \\
(2.20)\end{array}$ & $\begin{array}{c}-0.31 \\
(-1.00)\end{array}$ \\
\hline$a_{3}$ & $\begin{array}{l}-0.033 \\
(-0.07)\end{array}$ & $\begin{array}{c}-6.68 \\
(-0.11)\end{array}$ & $\begin{array}{c}0.31 \\
(0.52)\end{array}$ & $\begin{array}{c}1.2 \\
(0.55)\end{array}$ \\
\hline $\mathrm{a}_{4}$ & $\begin{array}{c}-0.31 \\
(-0.45)\end{array}$ & $\begin{array}{l}-88.21 \\
(-0.39)\end{array}$ & $\begin{array}{c}-0.36 \\
(-0.15)\end{array}$ & $\begin{array}{c}10.6 \\
(1.76)\end{array}$ \\
\hline $\mathrm{b}$ & $\begin{array}{c}0.19 \\
(0.49)\end{array}$ & $\begin{array}{c}0.08 \\
(0.06)\end{array}$ & $\begin{array}{c}0.22 \\
(0.73)\end{array}$ & $\begin{array}{c}-0.44 \\
(-1.41)\end{array}$ \\
\hline Total $\mathrm{R}^{2}$ & 0.27 & 0.53 & 0.45 & 0.29 \\
\hline
\end{tabular}
$\mathrm{e}_{\mathrm{t}}=\mathrm{be}_{\mathrm{t}-1}+\mathrm{v}_{\mathrm{t}}$

Significance Level: ${ }^{\mathrm{a}}=1 \% ;{ }^{\mathrm{b}}=5 \% ;{ }^{\mathrm{c}}=10 \%$ (t-stats in parentheses)
The estimates reported in Table 3 for the remaining variables are in line with those reported in Table 1 and Table 2. Current income in Costa Rica plays a positive and significant (at the 5\% level) role in determining current consumption. This supports the notion that liquidity constrained agent's consumption may respond to temporary changes in current income. In the remaining three countries current income is insignificant at any reasonable level. $\mathrm{C}_{\mathrm{t}-1}$ representing real permanent income, influences significantly only in the case of Guatemala.

\section{Concluding Remarks}

In this study we have attempted to empirically verify the role of an ever increasing national debt on economic activity. We did this through examining the debt neutrality thesis in four South American countries; namely, Costa Rica, El Salvador, Guatemala and Uruguay. The selection of the countries was purely based on the availability of appropriate data. The notion of debt neutrality has been overwhelmingly rejected in all cases leading to the conclusion that national debt has strong economic consequences aside from who will eventually pay the debt. The real burden of the debt becomes veritable in the face of continual high deficits. Particularly, when such deficits are structural in nature, as in most Latin American countries, or incurred for political ends. In addition deficits, primarily, those that outstrip the rate of growth of real GDP is extremely burdensome not only to the future generations, but to the current generation as well. Sizable government demand for funds to finance national debt raises the real interest rates, raise inflation and adversely affect the trade balance. When government is armed with additional funds via deficit financing, its demand for goods and services dwindles the amount of resources available for private consumption and investment. Diminution of investment leads to lower capital accumulation, decline in productivity and depresses the living standard. The problem becomes more acute when credit markets do not function competitively. To the extent that national debt is not neutral in its effect 
on the economy, one may find some solace in that a judicious countercyclical fiscal policy may be reasonably effective in allocating resources more efficiently.

\section{References}

1. Ando, A. and F. Modigliani " The Life-Cycle Hypothesis of Saving: Aggregate Implications and Tests," American Economic Review, May 1963.

2. Barro, R. "Are Government Bonds Net Wealth?," Journal of Political Economy, Nov.-Dec. 1972

3. _ _ "Public Debt and Taxes," in M. June Flanders-Assaf Razin, eds. Development in an inflationary World, New York: academic Press 1981.

4. Bernheim, Douglas, Andrei Shleifer, and Lawrence H. Summers. "Strategic Bequest Motive," Journal of Political Economy, Dec. 1985, 93, 1045-1076.

5. Buiter William H. and James Tobin. "Debt Neutrality: A Brief review of Doctrine and Evidence," in G. M. von Furstenberg, ed., Social Security and Private Saving, Cambridge, MA: Ballinger Publishing Co., 1979.

6. Darrat, Ali F. "Structural Federal Deficits and Interest Rates," Southern Economic Journal, Jan. 1990, 56, 752 59 .

7. Evans, Paul. "Do Large Deficits Produce High Interest Rares?," American Economic Review, March, 1985, 75, 68-87.

8. _ . "Interest Rates and Expected Future Deficits in the United States," Journal of Political Economy, February 1987, 95, 68-87.

9. _ _ _ Are Government Bonds Net Wealth?," Journal of Political Economy, October 1988, 96, 9831004.

10. Feldstein, Martin S. "Perceived Wealth in Bonds and Social Security: A Comment," Journal of Political Economy, April 1976, 84, 331-36.

11. _ _ _ "Governmnet Deficits and Aggregate Demand," Journal of Monetary Economics, Jan. 1982, 9, 120.

12. Hischorn Eric. "Rational Expectations and the Effects of Government Debt," Journal of Monetary Economics, July 1984, 14, 55-70.

13. Hall, Robert E. "Stochastic Implications of the Life Cycle-Permanent Income Hypothesis: Theory and Evidence," Journal of Political Economy, Dec. 1987, 86, 971-87.

14. Hoelscher, Gregory P. "Federal Borrowing and Short term Interest Rates," Southern Economic Journal, Feb. 1983, 319-33.

15. Kotlikoff, Lawrence J. and Lawrence Summers. "The Role of Intergenerational Transfers in Aggregate Capital Accumulation, Journal of Political Economy, Aug. 1981, 89, 706-732.

16. Leiderman, Leonardo and Mario I. Beljer. "Modeling and Testing Ricardian Equivalence: A Survey," IMF Staff Papers, March 1987, 34, 1-35.

17. Plosser, Chsarles I. "Government Financing Decision and Asset returns," Journal of Monetary Economics, May 1982, 325-52.

18. Weil, Phlippe. "Love Thy Children: Reflections on the Barro Debt Neutrality Theorem," Journal of Monetary Economics, May 1987, 19, 377-91. 
Notes 